
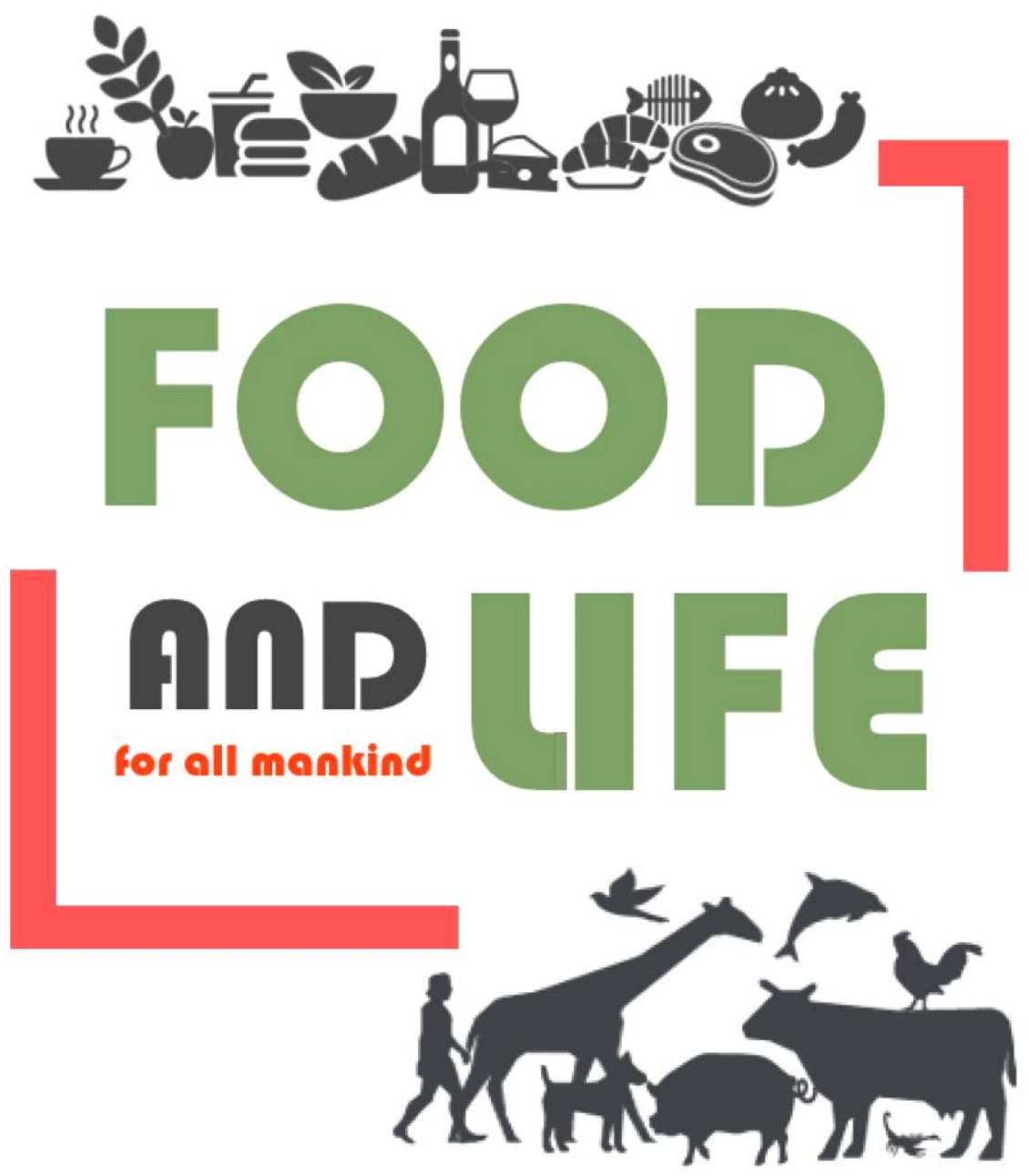

The Food and Life has published all type articles such as research articles, review articles, survey articles, research note, short communication or editorial since 2020. It covers the all scientific and technological aspects of food and life science.

\title{
https://www.foodnlife.org
}




\title{
인산염 대체제로서 치아씨드가 첨가된 건조 소시지의 품질 특성
}

\author{
신동민 ${ }^{1, \dagger}$, 김예지 ${ }^{1, \dagger}$, 김동현 ${ }^{2}$, 정현수 ${ }^{1}$, 한서구 ${ }^{1}$, 한종현 ${ }^{1}$, 박해정 ${ }^{1}$, 한성구 ${ }^{1 *}$ \\ ${ }^{1}$ 건국대학교 축산식품생명공학과 \\ ${ }^{2}$ (주미트뱅크 식품연구소
}

\section{Quality characteristics of chia seed-added dry sausage for replacement of phosphate}

Dong-Min Shin ${ }^{1, \dagger}$, Yea Ji Kim, ${ }^{1, \dagger}$ Dong Hyun Kim², Hyun Su Jung', Seo Gu Han', Jong Hyeon Han', Hae Jung Park', Sung Gu Han ${ }^{1, *}$

${ }^{1}$ Department of Food Science and Biotechnology of Animal Resources, Konkuk University, Seoul 05029, Korea

${ }^{2}$ Food Research Team, Meat Bank Corporation, Incheon 22650, Korea

\begin{abstract}
Phosphate is a widely used food additive for manufacturing processed meat product due to its water holding capacity by increasing the $\mathrm{pH}$ of meat batter. However, excessive phosphate consumption has been associated with the occurrence of some diseases including metabolic bone disease and chronic kidney disease. Therefore, this study evaluated the quality properties of chia seed (CS) as a replacement for phosphate in dry sausage. CS [1\%-3\% (w/w)] was added to produce dry sausage as a phosphate replacer. Quality characteristics including $\mathrm{pH}$, emulsion stability and lipid oxidation were significantly improved in CS-added dry sausage, compared with phosphate free-dry sausage ( $p<0.05)$. The lower lightness, redness and yellowness of CS significantly reduced color parameters of dry sausages $(\rho<0.05)$. Particularly, addition of $3 \%$ CS has the highest apparent viscosity and the lowest shear force among the groups $(p<0.05)$. Collectively, our data suggest that CS can replace phosphate in dry sausage without compromising quality characteristics.
\end{abstract}

Keywords: chia seed, dry sausage, phosphate, quality characteristic

서 론

인산염은 식육가공품에 널리 이용되는 첨가물로, 금속 이온 의 제거 및 액토미오신 복합체의 해리 유발 때문에 보수력 향 상에 기여하는 것으로 알려져 있다(Fonseca et al., 2011). 이러 한 요인으로 인산염은 식육가공품의 결착력, 유화 안정성 및 $\mathrm{pH}$ 의 향상에 기여하고 대표적으로 폴리인산나트륨(sodium tripolyphosphate)이 주로 이용된다(Kim et al., 2014). 그러나 비 교적 안전한 첨가물로 인식되어 있던 기존의 보고와는 달리, 인산염을 지속적으로 섭취하게 될 시 칼슘, 철, 마그네슘과 같 은 이온과 함께 불용성 염을 형성하여 뼈 질환 유발을 하거나 만성 신장병의 잠재적 위험성을 증가시킬 수 있다는 연구 보고 가 있다(Sherman and Mehta, 2009; Uribarri, 2009). 이에 식육 가공품 내 소금이나 아질산염 첨가량을 줄이는 연구뿐만 아니 라 인산염을 배제하려는 여러 노력이 이루어지고 있다(Park et al., 2008; Ruusunen et al., 2003). 특히, 천연 식품 첨가물 연구 에 대한 식품 산업의 관심은 지난 수십년간 지속적으로 증가하 고 있으며, 이는 소비자들의 합성 첨가물 무첨가 식품의 높은 선호도와 깊은 연관이 있다(Carocho et al., 2015).

살비아 히스파니카(Salvia hispanica)의 씨앗[chia seed (CS); 치아씨드]은 고대 멕시코 아즈텍 분명에서부터 경작되어 오던 작물로, 높은 식이섬유 및 단백질을 함유하고 있어 지방 결합 에 뛰어난 효과를 보인다(Coorey et al., 2014). 치아씨드의 주 요 지방산은 오메가 3 로 생선 알러지를 보유한 사람에게 좋은 지방 공급원으로 알려져 있으며, 풍부한 항산화 효과로 인한 질병 예방효과를 가질 수 있다(Mohd Ali et al., 2012; Kwon et al., 2019). 특히, 치아씨드는 물과 결합하면 수용성 점액을 외 피에 형성하여 특유의 겔을 형성한다(Câmara et al., 2020). 이 러한 특성을 이용하여 포화지방 대체제로서 치아씨드를 활용

\footnotetext{
${ }^{\dagger}$ These authors equally contributed to this study.

"Corresponding author : Sung Gu Han. Department of Food Science and Biotechnology of Animal Resources, Konkuk University, Seoul 05029, Korea. Tel: +82-2-450-0526, Fax: +82-2-4556-1044, E-mail: hansg@konkuk.ac.kr

This is an Open-Access article distributed under the terms of the Creative Commons Attribution Non-Commercial License which permits unrestricted non-commercial use, distribution, and reproduction in any medium, provided the original work is properly cited (http://creativecommons.org/licenses/by-nc/4.0/).
} 
한 돈육 소시지의 품질 특성, 에치움(Echium plantagineum L.) 유와 치아씨드 분말을 활용하여 지방산 조성을 개선한 볼로냐 소시지 연구 등 주로 지방 대체제에 관한 것을 다루었으나 이 경우 소시지 전체 중량 대비 5\%-10\%의 치아씨드 분말 첨가가 관능적 특성에 부정적인 영향을 주는 것으로 확인되었다 (Pintado et al., 2018; Pires et al., 2020). 한편, 영양적 품질 개 선을 위해 $3 \%$ 치아씨드 분말을 첨가한 프랑크푸르터와 항산화 제로서 $2 \%$ 치아씨드 추출물을 첨가한 돈육 소시지에 대한 연구 가 이루어졌으며, 이 경우 치아씨드의 첨가가 관능특성에 유의 적인 영향을 주지 않았다(Fernández-López et al., 2019; Scapin et al., 2015) 인산염 대체로서 치아씨드를 활용한 건조 소시지 에 관한 보고는 부족한 실정이다.

따라서 본 연구에서는 치아씨드의 겔 형성능을 식품에 활용 하는 연구의 일환으로 인산염 대신에 치아씨드를 첨가하여 건 조 소시지를 제조하고, 건조 소시지의 품질 특성을 비교하여 천연 인산염 대체제로서 치아씨드의 가능성을 조사하였다.

\section{재료 및 방법}

\section{실험 재료}

실험에 사용된 치아씨드 분말은 담원인터네셔널(Suwon, Gyeonggi, Korea)에서 구입하여 사용하였으며, 건조 소시지 배 합비 기준 각각 $1 \%, 2 \%, 3 \%$ 로 수화시킨 후 제조에 사용하였 다. 건조 소시지의 제조에 필요한 돼지 뒷다리와 등지방 부위 는 현지 시장에서 구입해 사용하였다.

\section{건조 소시지 제조}

돼지 뒷다리는 과도한 지방과 결체 조직을 제거하여 준비하 였고, 돼지 뒷다리와 등지방은 각각 분쇄기를 이용하여 $3 \mathrm{~mm}$ 크기로 분쇄하여 사용하였다. 소시지 유화물의 제조는 볼커터 (Cutter C4 VV, SIRMAN, Venezia, Italy)를 이용하여 원료육과 등지방, 얼음을 세절하면서 전체 중량에 대하여 정제염 $1 \%$, 시 즈닝 $1.2 \%$ 를 첨가하여 혼합하였다. 처리구는 Table 1 과 같이 인산염과 치아씨드의 첨가 여부 및 비율을 달리하여 5 처리구 로, 인산염을 $0.3 \%$ 첨가한 처리군 $(\mathrm{PC})$ 과 인산염을 첨가하지 않 은 처리군(NC) 및 치아씨드를 $1 \%$ 첨가한 처리군(CS1), 치아씨 드를 $2 \%$ 첨가한 처리군(CS2), 치아씨드를 $3 \%$ 첨가한 처리군 (CS3)으로 나누어 각 유화물을 제조하였다. 치아씨드 첨가 처 리군의 경우 치아씨드 수화과정에서 사용되는 얼음과 동량의 물 을 사용하였기 때문에 얼음을 첨가하지 않고 수화된 치아씨드를 첨가하였다. 제조된 유화물은 충진기(IS-8, Sirman, Marsango, Italy)를 사용하여 $130 \mathrm{~mm}$ 콜라겐 케이싱(COLFAN, Lodi, CA, USA)에 충진하였다. 건조는 $\mathrm{Kim}$ 등(2020)의 방법을 참고 및 변형하여 $55^{\circ} \mathrm{C}$ 에서 120 분, $65^{\circ} \mathrm{C}$ 에서 180 분, $80^{\circ} \mathrm{C}$ 에서 60 분간 1
Table 1. The formulation of dry sausages

\begin{tabular}{cccccc}
\hline \multirow{2}{*}{ Ingredients (\%) } & \multicolumn{5}{c}{ Dry sausage groups } \\
\cline { 2 - 6 } & PC & CS1 & CS2 & CS3 & NC \\
\hline Lean meat & 70 & 70 & 70 & 70 & 70 \\
Pork backfat & 10 & 10 & 10 & 10 & 10 \\
Ice (water) & 20 & 20 & 20 & 20 & 20 \\
Chia seed & 0 & 1 & 2 & 3 & 0 \\
Sodium & 0.3 & 0 & 0 & 0 & 0 \\
tripolyphosphate & & & & & \\
Salt & 1 & 1 & 1 & 1 & 1 \\
Seasoning & 1.2 & 1.2 & 1.2 & 1.2 & 1.2 \\
\hline PC.
\end{tabular}

PC, dry sausage with sodium tripolyphosphate; CS1, dry sausage with $1 \%$ chia seed; CS2, dry sausage with $2 \%$ chia seed; CS3, dry sausage with 3\% chia seed; NC, dry sausage without sodium tripolyphosphate.

차 건조, 탈피 후 $55^{\circ} \mathrm{C}$ 에서 120 분, $65^{\circ} \mathrm{C}$ 에서 180 분간 2 차 건조 하고 냉각하여 실험에 사용하였다.

\section{$\mathrm{pH}$ 측정}

$\mathrm{pH}$ 측정은 건조 전 유화물과 건조 소시지에 대해 이루어졌 으며, 각각 시료 $5 \mathrm{~g}$ 과 증류수 $20 \mathrm{~mL}$ 를 균질기(DAIHAN Scientific Co., Ltd., Gangwon, Korea)를 이용해 10,000 rpm에 서 1 분간 균질하였다. 균질액은 $\mathrm{pH}$ 측정기(LAQUA $\mathrm{pH}$ meter, Horiba, Kyoto, Japan)를 이용하여 4회 반복하여 측정하였다.

\section{색도 측정}

색도는 치아씨드 분말 및 건조 소시지의 표면에 대해 색도계 (CR-210, Minolta Camera, Osaka, Japan)를 이용하여 명도(L'), 적색도 $\left(\mathrm{a}^{*}\right)$, 황색도 $\left(\mathrm{b}^{*}\right)$ 를 측정하였고, 각각 3 회, 12 회 반복한 후 이의 평균을 구하였다.

\section{겉보기 점도 측정}

건조 전 유화물의 겉보기 점도는 회전형 레오미터(MCR92, Anton Paar, Graz, Austria)를 사용하여 전단 속도 0.1 에서 100 $1 / \mathrm{s}$ 범위에서 분석하였다. 온도조건은 $10^{\circ} \mathrm{C}$ 를 유지하였고 25 $\mathrm{mm}$ 직경의 평행 probe를 사용하였다. 측정은 3 회 반복한 후 각각의 평균을 구하였다.

\section{유화 안정성 측정}

유화물의 유화 안정성 측정은 da Silva 등(2019)의 방법에 따 라 측정하였다. 유화물은 $50 \mathrm{~mL}$ 시험관에 각 $25 \mathrm{~g}$ 을 충진하고 밀폐하였으며 항온수조에서 $80^{\circ} \mathrm{C}$ 로 30 분간 가열한 후 상온에 서 1 시간 냉각시켰다. 시험관에서 분리된 액체는 미리 무게를 재서 준비한 알루미늄 계량접시에 옮겨 $105^{\circ} \mathrm{C}$ 의 건조기에서 24 
시간 건조한 후 분리된 수분과 유분의 양을 계산하였다. 총 삼 출량, 수분 삼출량, 유분 삼출량은 아래의 식에 의하여 산출되었다.

\section{총 삼출량 $(\%)=$}

[분리된 액체의 무게 $(\mathrm{g}) /$ 유화물의 무게 $(\mathrm{g})] \times 100$

\section{수분 삼출량 $(\%)=$}

[\{분리된 액체의 무게 $(\mathrm{g})+$ 계량접시의 무게 $(\mathrm{g})$ 건조 후 계량접시의 무게 $(\mathrm{g})\}$ / 유화물의 무게 $(\mathrm{g})] \times 100$

유분 삼출량 $(\%)=$

[\{건조 후 계량접시의 무게 $(\mathrm{g})$ - 빈 계량접시의 무게 $(\mathrm{g})\}$ / 유화물의 무게 $(\mathrm{g})] \times 100$

\section{전단력 측정}

건조 소시지의 전단력은 de Huidobro 등(2005)의 방법에 따 라 측정하였다. 건조 소시지를 지름 $2.5 \mathrm{~cm}$, 길이 $5 \mathrm{~cm}$ 의 형태 로 자른 후 물성계(TA-XT2i, Stable Micro Systems, Surrey, $\mathrm{UK}$ )에 V blade를 설치하여 전단력을 측정하였다. 측정은 7회 반복하여 진행되었으며, peak의 값을 평균하여 나타냈다. 측정 조건은 pre-test speed $3.0 \mathrm{~mm} / \mathrm{s}$, test speed $1.0 \mathrm{~mm} / \mathrm{s}$, post-test speed $3.0 \mathrm{~mm} / \mathrm{s}$, distance $3.0 \mathrm{~mm}$ 이었다.

\section{지질 산패도 측정}

건조 소시지의 지질 산패도는 Shin 등(2017a)의 방법에 따라 thiobarbituric acid reactive substances(TBARS) 시험법을 이용 하여 측정하였다. 먼저 건조 소시지 $10 \mathrm{~g}$ 을 잘게 다진 후 증류 수 $50 \mathrm{~mL}$ 와 함께 균질기(Model AM-7, Nissei, Tokyo, Japan)로 $10,000 \mathrm{rpm}$ 에서 1 분간 균질하였다. 균질물은 증류수 $(47.5 \mathrm{~mL})$, $4 \mathrm{~N} \mathrm{HCl}(2.5 \mathrm{~mL})$, 소포제 $(1 \mathrm{~mL}, \mathrm{KMK}-73$, Shin-Etsu Silicone, Seoul, Korea)와 함께 증류 플라스크에 옮겨 담고, 증류하여 40 $\mathrm{mL}$ 의 증류액을 취하였다. 증류액 $(5 \mathrm{~mL})$ 은 $0.02 \mathrm{M} \mathrm{TBA}$ 시약
$(5 \mathrm{~mL})$ 과 혼합하여 $95^{\circ} \mathrm{C}$ 의 항온수조에서 30 분간 가열하고 냉 각한 후 $538 \mathrm{~nm}$ 에서 흡광도를 측정하였다. TBARS 값은 Han 등(2007)의 방법에 따라 측정된 흡광도 값에 7.8의 역가를 곱하 여 계산하였다.

\section{통계적 분석}

모든 실험은 3 회 이상 반복하여 진행되었고, 그 결과를 통계 프로그램 SPSS Ver. 24.0(SPSS Inc., Chicago, IL, USA)를 이 용하여 One-Way ANOVA를 실시하였다. 결과값은 평균 \pm 표준 편차로 나타냈으며, Duncan의 다중범위검정을 통해 $5 \%$ 의 유 의수준에서 처리구 간 차이에 대한 유의성을 검증하였다.

\section{결과 및 고찰}

\section{$\mathrm{pH}$ 및 색도}

인산염은 육제품에서 $\mathrm{pH}$ 의 증가와 근원섬유 단백질의 용해 유발을 주 목적으로 첨가하므로, $\mathrm{pH}$ 의 증가는 인산염 대체 연 구에 있어 중요한 지표로 여겨진다(Jeong et al., 2020). 건조 전 유화물과 건조 소시지의 $\mathrm{pH}$ 는 치아씨드 첨가 처리구 간에 유 의적 차이가 나타나지 않았으며 $(p>0.05)$, 건조 소시지의 $\mathrm{pH}$ 는 치아씨드 첨가 처리구가 인산염을 첨가하지 않은 처리구인 NC 보다 유의적으로 높은 값을 보였다(Table $2, p<0.05$ ). 본 연구에 서 사용된 치아씨드 분말의 $\mathrm{pH}$ 는 $6.24 \pm 0.02$ 로 돈육의 $\mathrm{pH}$ 보다 다소 높은 값을 지님에 따라 치아씨드의 첨가가 건조 소시지의 $\mathrm{pH}$ 를 높인 것으로 사료된다.

건조 소시지의 표면 색도를 측정하였을 때 치아씨드의 첨가는 건조 소시지의 색도에 유의적인 영향을 나타냈다(Table $2, p<0.05$ ). 건조된 소시지의 색도는 치아씨드의 첨가량이 증가함에 따라 명도 $\left(\mathrm{L}^{*}\right)$ 와 황색도 $\left(\mathrm{b}^{*}\right)$ 가 감소하였다. 이전의 연구에서 재구성 햄과 같은 저지방 육제품의 개발에 치아씨드를 첨가하였을 때, 유의적으로 낮은 $\mathrm{L}$ *값을 나타낸 것이 보고되었다(Ding et al., 2018). b*값의 감소는 실험에 사용된 치아씨드의 낮은 $b^{*}$ 값

Table 2. $\mathrm{pH}$ and color of dry sausages

\begin{tabular}{|c|c|c|c|c|c|c|}
\hline \multirow{2}{*}{\multicolumn{2}{|c|}{ Parameters }} & \multicolumn{5}{|c|}{ Dry sausage groups } \\
\hline & & \multirow{2}{*}{$\frac{P C}{5.89 \pm 0.04^{\text {a1) }}}$} & \multirow{2}{*}{$\frac{\text { CS1 }}{5.80 \pm 0.01^{b}}$} & \multirow{2}{*}{$\frac{\text { CS2 }}{5.83 \pm 0.01^{b}}$} & \multirow{2}{*}{$\frac{\text { CS3 }}{5.82 \pm 0.01^{b}}$} & \multirow{2}{*}{$\frac{N C}{5.81 \pm 0.04^{b}}$} \\
\hline & Batter & & & & & \\
\hline $\mathrm{pH}$ & Sausage & $6.08 \pm 0.02^{\mathrm{a}}$ & $6.02 \pm 0.01^{b}$ & $6.03 \pm 0.01^{b}$ & $6.02 \pm 0.01^{b}$ & $5.99 \pm 0.01^{\mathrm{c}}$ \\
\hline \multirow{3}{*}{ ClE } & $L^{*}$ & $9.86 \pm 0.47^{a}$ & $5.91 \pm 0.37^{c}$ & $5.30 \pm 0.23^{d}$ & $5.13 \pm 0.79^{d}$ & $6.64 \pm 0.48^{b}$ \\
\hline & $a^{*}$ & $18.46 \pm 0.59^{a}$ & $17.18 \pm 0.76^{b}$ & $16.63 \pm 0.72^{b}$ & $16.51 \pm 0.93^{b}$ & $17.02 \pm 0.77^{b}$ \\
\hline & $b^{*}$ & $20.93 \pm 0.61^{a}$ & $18.17 \pm 0.83^{b}$ & $17.46 \pm 0.70^{c}$ & $17.29 \pm 1.10^{c}$ & $18.28 \pm 0.78^{b}$ \\
\hline
\end{tabular}

${ }^{1)}$ Data are written as mean \pm SD.

${ }^{\text {a-d }}$ Significant difference was represented with different letters in each row $(\rho<0.05)$.

PC, dry sausage with sodium tripolyphosphate; CS1, dry sausage with $1 \%$ chia seed; CS2, dry sausage with $2 \%$ chia seed; CS3, dry sausage with $3 \%$ chia seed; NC, dry sausage without sodium tripolyphosphate. 
$(8.92 \pm 0.79)$ 의 영향인 것으로 판단된다. 적색도 $\left(\mathrm{a}^{*}\right)$ 의 경우 치아 씨드 첨가량에 따른 유의적인 차이는 나타나지 않았으나, 인산염 첨가 처리구보다 유의적으로 낮은 $\mathrm{a}^{*}$ 값을 나타냈으며 $(p<0.05)$, 이 또한 치아씨드의 낮은 $\mathrm{a}^{*}$ 값( $\left.2.32 \pm 0.23\right)$ 의 영향인 것으로 판단된 다. 이전 연구에서도 천연물 첨가 시 천연물 자체의 색이 제품 색도에 영향을 줄 수 있음이 보고되었다(Jeong et al., 2020; Jeong et al., 2021). 따라서 본 논문에서 치아씨드의 첨가는 건 조 소시지의 색도에 영향을 미친 것으로 사료된다.

\section{겉보기 점도}

건조 전 유화물(meat batter)에 대한 겉보기 점도는 치아씨드 를 첨가함에 따라 인산염을 첨가한 $\mathrm{PC}$ 보다 높은 겉보기 점도 를 나타냈다(Fig. $1, p<0.05$ ). 치아씨드 첨가량 $1 \%$ 또는 $2 \%$ 에 서는 $\mathrm{PC}$ 와 유사한 정도의 점도를 보였으나, 치아씨드 $3 \%$ 첨가 한 $\mathrm{CS} 3$ 에서는 유의적으로 높은 점도를 나타냈다 $(p<0.05)$. 이러 한 결과는 치아씨드에 함유된 식이섬유의 효과로 사료된다. 식 이섬유가 풍부한 천연물을 첨가한 육제품에 대한 이전 연구에 서도 이와 유사한 결과가 보고되었다. Ham 등(2017)은 연꽃 분 말을 첨가한 가열 소시지에 대한 연구에서 연꽃 분말을 첨가한 고기 유화물은 첨가하지 않은 경우보다 높은 겉보기 점도를 보 였으며, Zhao 등(2018)은 재생 셀룰로오스 섬유(regenerated cellulose fiber)를 첨가한 유화형 소시지 연구에서 셀룰로오스 섬유 첨가량이 높은 처리구의 겉보기 점도가 증가하였다고 보 고하였다. 겉보기 점도는 유화 안정성과 보수력에 긍정적인 영 향을 줄 수 있으며(Shin et al., 2017b), 본 논문에서는 건조 소 시지 유화물에 치아씨드를 첨가하는 것이 겉보기 점도를 상승 시킴을 확인하였다.

\section{유화 안정성}

건조 소시지의 유화 안정성은 인산염을 첨가하지 않은 $\mathrm{NC}$ 에서 $15.07 \%$ 로 가장 많은 총 삼출량을 나타냈고, 치아씨드의 함량이 증가함에 따라 삼출량이 감소하였다(Table $3, p<0.05$ ). 이러한 결과는 치아씨드 식이섬유에 의한 점도 상승의 영향으 로 판단되며, Choi 등(2011)은 유화물의 점도는 유화 안정성과

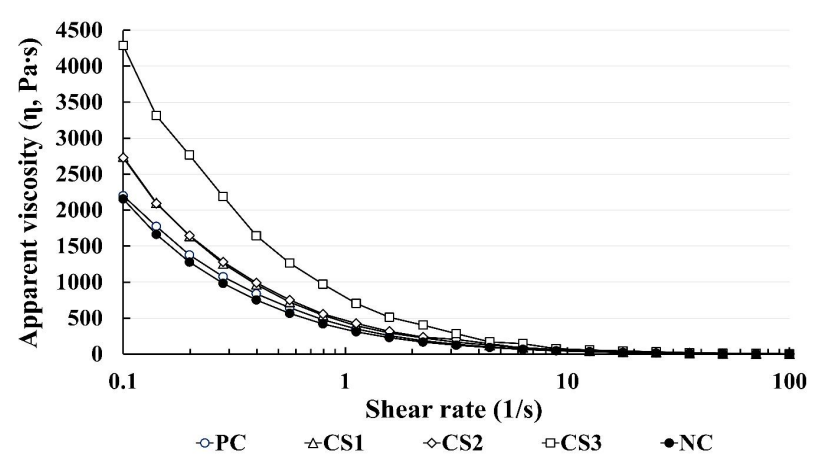

Fig. 1. Apparent viscosity of meat batters containing chia seed. Measurement of apparent viscosity was conducted at $10^{\circ} \mathrm{C}$ and shear rate was from 0.1 to 100 $1 / \mathrm{s}$. Each line with different symbol means different treatment. PC, dry sausage with sodium tripolyphosphate; CS1, dry sausage with $1 \%$ chia seed; CS2, dry sausage with $2 \%$ chia seed; CS3, dry sausage with $3 \%$ chia seed; NC, dry sausage without sodium tripolyphosphate.

밀접한 연관이 있다고 보고하였다. 이전 연구에서는 볼로냐 소 시지의 지방 대체 목적으로 에멀젼 겔에 치아씨드를 첨가하였 을 때 분리대두단백을 첨가한 에멀젼 겔보다 최종 제품의 유화 안정성이 향상된 것으로 보고되었으며(de Souza Paglarini et al., 2019), 또 다른 연구에서 소시지의 인산염 대체 목적으로 L-Arginine을 첨가한 경우에는 인산염 첨가 처리구와 유화 안 정성에서 유의적 차이가 없음을 확인하였다(Kim et al., 2014). 육제품 제조 시 첨가된 인산염은 근원섬유 단백질 용해에 의한 염용성 단백질의 추출에 관여하기 때문에 유화 안정성과 밀접 한 관계를 나타낸다(O'Flynn et al., 2014). 이에 따라서 본 논문 에서는 건조 소시지에서 치아씨드를 첨가하는 것이 인산염 대 체제로서 유화 안정성 향상 효과가 있음을 확인하였다.

\section{전단력}

건조 식육가공품의 연도(tenderness)는 제품의 품질을 결정 하는 중요한 요인 중 하나로 알려져 있으며, 이는 소비자의 선 택과 직접적인 관련이 있다(Miller et al., 2001). 전단력 측정은

Table 3. Emulsion stability of dry sausages

\begin{tabular}{lcccccc}
\hline \multirow{2}{*}{ Parameters } & \multicolumn{5}{c}{ Dry sausage groups } \\
\cline { 3 - 6 } & Total (\%) & $10.63 \pm 0.31^{\mathrm{d} 1)}$ & $15.45 \pm 0.43^{\mathrm{a}}$ & $14.21 \pm 0.92^{\mathrm{b}}$ & $12.87 \pm 0.73^{\mathrm{c}}$ & $15.07 \pm 0.41^{\mathrm{ab}}$ \\
\multirow{2}{*}{ Fluid } & Water (\%) & $10.04 \pm 0.29^{\mathrm{d}}$ & $14.55 \pm 0.42^{\mathrm{a}}$ & $13.37 \pm 0.85^{\mathrm{b}}$ & $12.04 \pm 0.69^{\mathrm{c}}$ & $14.19 \pm 0.39^{\mathrm{ab}}$ \\
release & Oil (\%) & $0.59 \pm 0.02^{\mathrm{b}}$ & $0.91 \pm 0.02^{\mathrm{a}}$ & $0.84 \pm 0.07^{\mathrm{a}}$ & $0.83 \pm 0.04^{\mathrm{a}}$ & $0.88 \pm 0.01^{\mathrm{a}}$ \\
& & &
\end{tabular}

${ }^{1)}$ Data are written as mean \pm SD.

${ }^{a-d}$ Significant difference was represented with different letters in each row $(\alpha<0.05)$.

PC, dry sausage with sodium tripolyphosphate; CS1, dry sausage with $1 \%$ chia seed; CS2, dry sausage with $2 \%$ chia seed; CS3, dry sausage with $3 \%$ chia seed; NC, dry sausage without sodium tripolyphosphate. 
Table 4. Shear force and thiobarbituric acid reactive substances (TBARS) value of dry sausages

\begin{tabular}{cccccc}
\hline \multirow{2}{*}{ Parameters } & \multicolumn{5}{c}{ Dry sausage groups } \\
\cline { 2 - 5 } & PC & CS1 & CS2 & CS3 & NC \\
\hline Shear force $(\mathrm{kg})$ & $5.49 \pm 0.59^{\text {cd1 }}$ & $6.26 \pm 0.40^{\mathrm{ab}}$ & $5.91 \pm 0.41^{\mathrm{bc}}$ & $5.25 \pm 0.73^{\mathrm{d}}$ & $6.78 \pm 0.54^{\mathrm{a}}$ \\
MDA (mg/kg) & $1.06 \pm 0.01^{\mathrm{e}}$ & $3.60 \pm 0.01^{\mathrm{b}}$ & $2.04 \pm 0.01^{\mathrm{c}}$ & $1.70 \pm 0.01^{\mathrm{d}}$ & $4.64 \pm 0.03^{\mathrm{a}}$ \\
\hline
\end{tabular}

${ }^{1)}$ Data are written as mean \pm SD.

${ }^{a-e}$ Significant difference was represented with different letters in each row $(\propto 0.05)$.

PC, dry sausage with sodium tripolyphosphate; CS1, dry sausage with $1 \%$ chia seed; CS2, dry sausage with $2 \%$ chia seed; CS3, dry sausage with $3 \%$ chia seed; NC, dry sausage without sodium tripolyphosphate; MDA, malondialdehyde content in TBARS assay.

식육가공품의 연도를 기계적으로 측정하는 방법으로 높은 전 단력을 가진 식육가공품은 소비자의 기호도에 부정적인 영향을 줄 수 있다(Culioli, 1995; Destefanis et al., 2008). Table 4는 인산 염 및 치아씨드 첨가량을 달리한 건조 소시지의 전단력 측정 결과 를 나타낸 표이다. 건조 소시지의 전단력은 $\mathrm{NC}$ 와 치아씨드 $1 \%$ 를 첨가한 처리구가 가장 높게 나타났으며 $(p<0.05)$, 치아씨드 첨가량 이 증가함에 따라 유의적으로 전단력이 감소하는 경향을 나타냈 다 $(p<0.05)$. 이러한 결과는 치아씨드의 풍부한 식이섬유 $(18 \%$ $30 \%)$ 및 지방 $(30 \%-33 \%)$ 함유량에 의한 것으로 사료된다(Ixtaina et al., 2008). 이전의 연구에 따르면 지방 함량을 달리한 건조 오 리육 소시지에서 지방함량이 증가함에 따라 전단력이 유의적으로 감소하는 경향을 보였으며, 쌀겨 식이섬유를 첨가한 반 건조 돈육 육포 또한 쌀겨 식이섬유 첨가량이 증가함에 따라 보수력이 증진 하여 연도가 개선되었음을 확인하였다(Lorenzo et al., 2011).

\section{지질 산패도}

치아씨드를 첨가한 건조 소시지의 지질 산패도 측정 결과는 Table 4에 나타냈다. 인산염을 첨가한 PC가 가장 낮은 지질 산 패도를 나타냈으며 $(p<0.05)$, 다음으로 치아씨드 첨가량이 증가 함에 따라 유의적으로 낮은 지질 산패도를 나타냈다 $(p<0.05)$. 치아씨드 첨가량에 따른 지질 산패도의 감소는 치아씨드의 항 산화 효과로 설명할 수 있다. 치아씨드에는 토코페롤, 파이토스 테롤(phytosterol), 카르티노이드 및 페놀 화합물 등이 존재하여 강력한 항산화제 역할을 하는 것으로 알려져 있다(da Silva Marineli et al., 2015). 이전 연구에서는 치아씨드 분말을 첨가 한 계육 소시지의 저장 기간에 따른 지질 산패도 측정 결과 치 아씨드 함량이 증가함에 따라 유의적으로 낮은 지질 산패도를 보이기도 하였다(Mohamed and Safaa, 2019). 따라서 치아씨드 를 처리한 처리구 모두 대조구인 인산염 무첨가 처리구에 비해 유의적으로 낮은 지질 산패도를 보였고, 치아씨드 분말을 첨가 한 건조 소시지의 저장성 향상이 우수하다고 판단된다.

\section{요약}

본 연구는 식육가공품에 이용되는 인산염 대체재로서 치아
씨드 첨가가 건조 소시지에 미치는 영향을 확인하기 위해 수행 되었다. 본 연구에 사용된 치아씨드는 분말을 증류수에 수화하 여 건조 소시지 제조에 사용하였다. 건조 소시지의 $\mathrm{pH}$ 측정 결 과, $\mathrm{NC}$ (인산염 무첨가 처리구)에 비해 치아씨드 첨가 처리구가 높은 $\mathrm{pH}$ 를 나타냈으나, 치아씨드 첨가량에 의존적으로 증가하 지 않았다. 색도의 경우 치아씨드의 낮은 $\mathrm{L}^{*}, \mathrm{a}^{*}$ 및 $\mathrm{b}^{*}$ 값에 영향 을 받아 건조소시지에 유의적인 영향을 끼쳤다. 유화물 겉보기 점도의 경우 치아씨드 첨가량에 비례하는 경향을 보였으며, 이 는 치아씨드 내 식이섬유에 의한 것으로 사료된다. 유화 안정 성의 경우 $\mathrm{PC}($ 인산염 첨가 처리구)가 가장 안정적인 경향을 보 였으나, 치아씨드 $3 \%$ 첨가 처리구는 $\mathrm{NC}$ 에 비하여 유의적으로 높은 유화 안정성을 보였다 $(p<0.05)$. 치아씨드 첨가량이 증가 함에 따라 유의적으로 전단력이 감소하였으며 $(p<0.05)$, 지질 산패도는 치아씨드 첨가에 따라 유의적으로 낮은 $\mathrm{MDA}$ 함량을 나타냈다 $(p<0.05)$. 본 연구의 결론으로서, 치아씨드의 첨가는 점도 증가에 따른 유화 안정성 증진 및 식이섬유 함량 증가에 따른 전단력 감소를 통해 부드러운 식감을 가지며 지질 산패가 적은 건조소시지의 제조가 가능할 것으로 판단된다.

\section{Conflicts of Interest}

The authors declare no potential conflict of interest.

\section{Acknowledgments}

This research was funded by the Main Research Program (PJ016373) of the Foundation of Agri. Tech. Commercialization \& Transfer.

\section{Ethics Approval}

This article does not require IRB/IACUC approval because there are no human and animal participants

\section{Author Contributions}

Conceptualization: Shin DM, Kim YJ, Kim DH 
Data curation: Shin DM, Kim YJ

Formal analysis: Shin DM, Kim YJ

Methodology: Shin DM, Kim YJ

Software: Shin DM, Kim YJ

Validation: Shin DM, Kim YJ

Investigation: Shin DM, Kim YJ, Jung HS Han SG, Han JH, Park HJ

Writing - original draft: Shin DM, Kim YJ

Writing - review \& editing: Shin DM, Kim YJ, Kim DH,

Jung HS, Han SG, Han JH, Park HJ, Han SG

\section{Author Information}

Dong-Min Shin (Graduate Student, Konkuk University) https://orcid.org/0000-0003-2755-433X

Yea Ji Kim (Graduate Student, Konkuk University) https://orcid.org/0000-0003-0937-5100

Dong Hyun Kim (Researcher, Meat Bank Corporation) https://orcid.org/0000-0002-0211-6459

Hyun Su Jung (Undergraduate Student, Konkuk University) https://orcid.org/0000-0002-3491-8317

Seo Gu Han (Graduate Student, Konkuk University) https://orcid.org/0000-0001-5100-7446

Jong Hyeon Han (Graduate Student, Konkuk University) https://orcid.org/0000-0002-3339-6844

Hae Jung Park (Undergraduate Student, Konkuk University) https://orcid.org/0000-0002-8676-2799

Sung Gu Han (Professor, Konkuk University) https://orcid.org/0000-0002-1485-861X

\section{References}

Câmara AKFI, Geraldi MV, Okuro PK, Júnior MRM, da Cunha RL, Pollonio MAR. 2020. Satiety and in vitro digestibility of low saturated fat bologna sausages added of chia mucilage powder and chia mucilage-based emulsion gel. J Funct Foods 65:103753.

Carocho M, Morales P, Ferreira ICFR. 2015. Natural food additives: Quo vadis? Trends Food Sci Technol 45:284-295.

Choi YS, Kim HW, Song DH, Cho JH, Park JH, Kim MY, Lim CS, Kim CJ. 2011. Quality characteristics and sensory properties of reduced-fat emulsion sausages with brown rice fiber. Korean J Food Sci Anim Resour 31:521-529.

Coorey R, Tjoe A, Jayasena V. 2014. Gelling properties of chia seed and flour. J Food Sci 79:E859-E866.

Culioli J. 1995. Meat tenderness: Mechanical assessment. In
Expression of tissue proteinases and regulation of protein degradation as related to meat quality. Ouali A, Demeyer DI, Smulders FJM (ed). European Consortium for Continuing Education in Advanced Meat Science and Technology [ECCEAMST], Utrecht, Netherlands. pp 239-266.

da Silva Marineli R, Lenquiste SA, Moraes ÉA, Maróstica MR Jr. 2015. Antioxidant potential of dietary chia seed and oil (Salvia hispanica L.) in diet-induced obese rats. Food Res Int 76:666-674.

da Silva SL, Amaral JT, Ribeiro M, Sebastião EE, Vargas C, de Lima Franzen F, Schneider G, Lorenzo JM, Fries LLM, Cichoski AJ, Campagnol PCB. 2019. Fat replacement by oleogel rich in oleic acid and its impact on the technological, nutritional, oxidative, and sensory properties of bologna-type sausages. Meat Sci 149:141-148.

de Huidobro FR, Miguel E, Blázquez B, Onega E. 2005. A comparison between two methods (Warner-Bratzler and texture profile analysis) for testing either raw meat or cooked meat. Meat Sci 69:527-536.

de Souza Paglarini C, de Figueiredo Furtado G, Honório AR, Mokarzel L, da Silva Vidal VA, Ribeiro APB, Cunha RL, Pollonio MAR. 2019. Functional emulsion gels as pork back fat replacers in bologna sausage. Food Struct 20:100105.

Destefanis G, Brugiapaglia A, Barge MT, Dal Molin E. 2008. Relationship between beef consumer tenderness perception and Warner-Bratzler shear force. Meat Sci 78:153-156.

Ding Y, Lin HW, Lin YL, Yang DJ, Yu YS, Chen JW, Wang SY, Chen YC. 2018. Nutritional composition in the chia seed and its processing properties on restructured ham-like products. J Food Drug Anal 26:124-134.

Fernández-López J, Lucas-González R, Viuda-Martos M, Sayas-Barberá E, Navarro C, Haros CM, Pérez-Álvarez JA. 2019. Chia (Salvia hispanica L.) products as ingredients for reformulating frankfurters: Effects on quality properties and shelf-life. Meat Sci 156:139-145.

Fonseca B, Kuri V, Zumalacárregui JM, Fernández-Diez A, Salvá BK, Caro I, Osorio MT, Mateo J. 2011. Effect of the use of a commercial phosphate mixture on selected quality characteristics of 2 Spanish-style dry-ripened sausages. J Food Sci 76:S300-S305.

Ham YK, Hwang KE, Song DH, Kim YJ, Shin DJ, Kim KI, Lee HJ, Kim NR, Kim CJ. 2017. Lotus (Nelumbo nucifera) rhizome as an antioxidant dietary fiber in cooked sausage: Effects on physicochemical and sensory characteristics. 
Korean J Food Sci Anim Resour 37:219-227.

Han DJ, Jeong JY, Choi JH, Choi YS, Kim HY, Lee MA, Lee ES, Paik HD, Kim CJ. 2007. Effects of drying conditions on quality properties of pork jerky. Korean J Food Sci Anim Resour 27:29-34.

Ixtaina VY, Nolasco SM, Tomas MC. 2008. Physical properties of chia (Salvia hispanica L.) seeds. Ind Crops Prod 28:286-293.

Jeong CH, Lee SH, Kim HY. 2021. Influence of the quality characteristics and antioxidant activity according to the storage period of emulsion-type pork sausage containing kabocha powder. J Korean Soc Food Sci Nutr 50:272-278.

Jeong HG, Jo K, Lee S, Cho YS, Jung S. 2020. Substitution of phosphate and ISP by allomyrina dichotoma larvae powder in emulsion sausage. Anim Anim Resour Sci 31: 134-144.

Kim SM, Kim TK, Ku SK, Kim MJ, Jung S, Yong HI, Choi YS. 2020. Quality characteristics of semi-dried restructured jerky: combined effects of duck skin gelatin and carrageenan. J Anim Sci Technol 62:553-564.

Kim YD, Lee JS, Park JH, Park DC, Jeon YS, In MJ, Oh NS. 2014. Application of 1-arginine as a substitute for inorganic polyphosphate in pork sausage production. J Appl Biol Chem 57:171-174.

Kwon HC, Bae H, Seo HG, Han SG. 2019. Short communication: chia seed extract enhances physiochemical and antioxidant properties of yogurt. J Dairy Sci 102:4870-4876.

Lorenzo JM, Temperán S, Bermúdez R, Purriños L, Franco D. 2011. Effect of fat level on physicochemical and sensory properties of dry-cured duck sausages. Poult Sci 90:13341339.

Miller MF, Carr MA, Ramsey CB, Crockett KL, Hoover LC. 2001. Consumer thresholds for establishing the value of beef tenderness. J Anim Sci 79:3062-3068.

Mohamed RAA, Safaa AL. 2019. Effect of incorporation of chia seeds flour in chicken sausage on TBA values and microbial quality during cooling storage. Suez Canal Univ J Food Sci 6:97-103.

Mohd Ali NM, Yeap SK, Ho WY, Beh BK, Tan SW, Tan SG. 2012. The promising future of chia, Salvia hispanica L. J Biomed Biotechnol 2012:171956.

O'Flynn CC, Cruz-Romero MC, Troy DJ, Mullen AM, Kerry JP. 2014. The application of high-pressure treatment in the reduction of phosphate levels in breakfast sausages. Meat
Sci 96:633-639.

Park KS, Choi YI, Lee SH, Kim CH, Auh JH. 2008. Application of functional carbohydrates as a substitute for inorganic polyphosphate in pork meat processing. Korean J Food Sci Technol 40:118-121.

Pintado T, Herrero AM, Jiménez-Colmenero F, Pasqualin Cavalheiro C, Ruiz-Capillas C. 2018. Chia and oat emulsion gels as new animal fat replacers and healthy bioactive sources in fresh sausage formulation. Meat Sci 135:6-13.

Pires MA, Barros JC, Rodrigues I, Munekata PES, Trindade MA. 2020. Improving the lipid profile of bologna type sausages with Echium (Echium plantagineum L.) oil and chia (Salvia hispanica L) flour. LWT 119:108907.

Ruusunen M, Vainionpää J, Puolanne E, Lyly M, Lähteenmäki L, Niemistö M, Ahvenainen R. 2003. Physical and sensory properties of low-salt phosphate-free frankfurters composed with various ingredients. Meat Sci 63:9-16.

Scapin G, Schimdt MM, Prestes RC, Ferreira S, Silva AFC, da Rosa CS. 2015. Effect of extract of chia seed (Salvia hispanica) as an antioxidant in fresh pork sausage. Int Food Res J 22:1195-1202.

Sherman RA, Mehta O. 2009. Phosphorus and potassium content of enhanced meat and poultry products: implications for patients who receive dialysis. Clin J Am Soc Nephrol 4:1370-1373.

Shin DM, Hwang KE, Lee CW, Kim TK, Park YS, Han SG. 2017a. Effect of swiss chard (Beta vulgaris var. Cicla) as nitrite replacement on color stability and shelf-life of cooked pork patties during refrigerated storage. Korean J Food Sci Anim Resour 37:418-428.

Shin HB, Kim HY, Chun JY. 2017b. Quality characteristics of emulsion-type chicken sausages added different level of buckwheat powder. Korean J Poult Sci 44:135-141.

Uribarri J. 2009. Phosphorus additives in food and their effect in dialysis patients. Clin J Am Soc Nephrol 4:1290-1292.

Zhao Y, Hou Q, Zhuang X, Wang Y, Zhou G, Zhang W. 2018. Effect of regenerated cellulose fiber on the physicochemical properties and sensory characteristics of fat-reduced emulsified sausage. LWT 97:157-163.

(c) Copyright. Korean Society for Food Science of Animal Resources.

Date Received Sep. 27, 2021

Date Revised Oct. 18, 2021

Date Accepted Oct. 19, 2021 